\title{
Growth and Diversification of Mountain Agriculture: A Case Study of Himachal Pradesh
}

\author{
Nisha Devi* and R.S. Prasher \\ Department of Social Sciences, Dr. Y.S Parmar University of Horticulture and Forestry, Nauni, Solan, Himachal Pradesh, India \\ "Corresponding author: nishathakuroachghat@gmail.com
}

\begin{abstract}
In the context of hill agriculture, diversification has occurred both across and within crop, livestock and forestry sectors. Agriculture, in its broader sense is the mainstay of mountain people. Diversification in agriculture has become necessary for developing countries since growing of basic staples such as cereals alone cannot support economic development, notwithstanding the need to ensure food security to the people. Diversification with commercial crops is now a key strategy that can increase agricultural incomes and minimize risks due to crop failures and further help in poverty alleviation, employment planning and environmental conservation. The present study was undertaken to probe into changes in cropping pattern, region wise levels of diversification and determinants of diversification both at macro and micro level. Diversification in different districts of Himachal Pradesh was assessed by using Herfindahl index. Regression analysis was carried out by using Herfindahl index at macro level for the selected period from 1972-73 to 2011-12 and Entropy Index at micro level to find out the determinants of crop diversification. Diversification towards high value cash crops in most of the districts (ten) did take place, but its intensity was quite pronounced in Lahaul \& Spiti, Kinnaur, Shimla and Kullu where the increase in area under the non-foodgrains varied from 17.18 per cent to 57.47 per cent over the study period. The ongoing process of crop diversification in the state has become evident from rising proportion of gross cropped area under fruit and vegetable crops as per present study.
\end{abstract}

Keywords: Herfindahl index, Entropy Index, Cropping pattern, Regression analysis, Temporal and Spatial

The agriculture occupies an important position in the current scenario of Himachal Pradesh and is considered the backbone of its economy as it is the main stake of livelihood for two third of rural population in the state. In contemporary development theory, the agricultural and rural sectors of less developed countries are believed to be key sectors in attaining desired development and growth objectives (Reynolds, 1975; Todaro, 1989). Traditionally agriculture is seen as source of food and raw material for the economy and its people. It is also seen as a source of income and employment. Efforts are on to diversify agricultural activities in the rural areas to increase production and productivity through improvement of inputs, transfer of appropriate technology and managerial practices. Considering the dimension of the unemployment situation in the state, particularly in the rural areas, diversification of economic activities for self-employment in rural areas has become very important. There is thus an urgent need to diversify agriculture into high yielding activities, which would generate employment, ensure greater rate of returns to the farmers and promote self-reliance. According to Braun (1995) apart from income generation, diversification would in most instances increase employment opportunities for the rural poor, the benefits of which would be substantial and be distributed across a broad spectrum of the economy.

Traditionally, mountain agriculture has been an integrated system of farm and related activities that could be sustained through the use of local natural and human resources. The different inter-related mountain features, often termed as mountain specificities include inaccessibility (or restricted 
accessibility), fragility, marginality, diversity, niche and specific human adaptation mechanism to the above features. Many of these features are not only interlinked (in impacts etc.) but have social dimensions as well. These features create objective circumstances, which in turn present a range of opportunities and constraints for agriculture and influence human responses to them (Jodha, 1992). The diversification of agriculture towards selective high-value cash crops including fruits and vegetables, compatible with the comparative advantage of the region, is suggested as a viable solution to stabilize and raise farm incomes, increase employment opportunities for small and marginal farmers, boost exports and conserve and enhance the natural resource base, principally land and water (Vyas, 1996; Chand, 1996; Joshi et al. 2004; Sharma, 2005).

\section{MATERIALS AND METHODS}

Two types of analysis were carried out i.e. macrolevel analysis carried out at the state and regional level with the help of secondary data for the period 1972-73 to 2011-12 and micro-level analysis for studying diversification with the help of primary data collected from 240 sample farms from four agro-climatic zones of Himachal Pradesh for the agricultural year 2016-17. Himachal Pradesh comprise of four zones and twelve districts. One district from each agro-climatic zone was selected purposively. Two blocks from each selected district were purposively selected, one relatively highly diversified and one relatively least diversified in consultation with district level officers. Accordingly, 30 households were selected from each block thus making total sample size of 240 from four agroclimatic zones of Himachal Pradesh (Table 1).

Extent of diversification: Level of diversification is measured by using Herfindahl index.

$$
\text { H.I. }=\sum_{i=1}^{N} P i^{2}
$$

It ranges between 0 to 1 . Where $\mathrm{N}$ is total number of crops and Pi represents acreage proportion of the $\mathrm{i}^{\text {th }}$ crop in total cropped area. It is a measure of concentration and assume the value 0 at full diversification and 1 at full concentration.

\section{Determinants of diversification}

In order to identify the major determinants of diversification at macro level in the state, a step wise regression analysis with Herfindahl index as the dependent variable was carried out in the present study using time series data for the selected explanatory variables from 1972-73 to 2011-12. As pointed out earlier the independent factors considered for this analysis were as under; $X_{1}=$ Annual Rainfall $(\mathrm{mm}), X_{2}=$ Fertilizer use $(\mathrm{kg} /$ hectare), $X_{3}=$ Per cent of gross irrigated area to gross cultivated area, $X_{4}=$ Road Length (Sq. Km/1000 hectares of grossed cropped area), $X_{5}=$ Per capita Income (₹) at constant price, $X_{6}=$ Average size of land holding (ha/farm) and $X_{7}=$ Number of regulated markets (per 1000 ha of gross cropped area).

To know the determinants of diversification at micro level, Entropy index calculated at household levels for each zone/district were regressed on different explanatory variables by using the multiple regression analysis.

$$
Y=a_{0}+b_{1} X_{1}+b_{2} X_{2}+\ldots . .+B_{n} X_{n}+u
$$

Where: $Y=$ Entropy Index, $X_{1}=$ Farm size, $X_{2}=$ Family members engaged in agriculture, $X_{3}=$ Ratio of gross irrigated area to gross cropped area, $X_{4}$ $=$ Non-farm income, $X_{5}=$ Age of the head of the family, $X_{6}=$ Education of the head of the family, $X_{7}$ $=$ Per bigha capital investment, $u=$ Error term

Table 1: Details of selected districts and development blocks

\begin{tabular}{ccccc}
\hline \multirow{2}{*}{ Zones } & Districts & \multicolumn{2}{c}{ Development Blocks } & \multirow{2}{*}{$\begin{array}{c}\text { No. of selected } \\
\text { farmers }\end{array}$} \\
\cline { 3 - 4 } & & Highly diversified & Less diversified & 30 each \\
Sub-montane low hills & Bilaspur & Sadar & Jandutha & 30 each \\
Mid hills sub-humid & Solan & Solan & Kunihar & 30 each \\
High hills temperate wet & Kullu & Kullu & Anni & Po each \\
High hills temperate dry & Kinnaur & Kalpa & Pooh & $\mathbf{2 4 0}$ \\
\hline Total & & & &
\end{tabular}




\section{Entropy Index (E.I)}

$$
\text { E.I. }=\sum_{i=1}^{N} p i \times \log (1 / P i)
$$

The Entropy Index would increase with the increase in diversification and it approaches zero when there is perfect concentration. The upper value of index can exceed one, when the figure for number of crops is higher than the value of logarithmic base.

\section{RESULTS AND DISCUSSION}

The extent of crop diversification in Himachal Pradesh during 1972-73 to 2011-12 as measured by Herfindahl index has been presented in Table 2 . Agriculture in the State remained highly diversified over the years from 1972-73 and 2011-12 with marginal tendency towards specialization as denoted by the increasing values of Herfindahl index.

Table 2: Temporal and spatial extent of crop diversification in Himachal Pradesh: 1972-73 to 201112

\begin{tabular}{cccccc}
\hline \multirow{2}{*}{$\begin{array}{c}\text { District/ } \\
\text { Index }\end{array}$} & \multicolumn{5}{c}{ Periods } \\
\cline { 2 - 6 } & $\mathbf{1 9 7 2 - 7 3}$ & $\mathbf{1 9 8 1 - 8 2}$ & $\mathbf{1 9 9 1 - 9 2}$ & $\mathbf{2 0 0 1 - 0 2}$ & $\mathbf{2 0 1 1 - 1 2}$ \\
\hline Bilaspur & 0.305 & 0.344 & 0.398 & 0.430 & 0.433 \\
Chamba & 0.253 & 0.274 & 0.309 & 0.282 & 0.286 \\
Hamirpur & 0.258 & 0.370 & 0.435 & 0.453 & 0.462 \\
Kangra & 0.253 & 0.259 & 0.280 & 0.290 & 0.303 \\
Kinnaur & 0.297 & 0.068 & 0.195 & 0.145 & 0.297 \\
Kullu & 0.213 & 0.208 & 0.230 & 0.225 & 0.220 \\
Lahaul \& & 0.262 & 0.259 & 0.222 & 0.229 & 0.336 \\
Spiti & & & & & \\
Mandi & 0.240 & 0.112 & 0.287 & 0.286 & 0.304 \\
Shimla & 0.184 & 0.162 & 0.172 & 0.193 & 0.311 \\
Sirmour & 0.252 & 0.265 & 0.266 & 0.243 & 0.212 \\
Solan & 0.250 & 0.256 & 0.287 & 0.294 & 0.318 \\
Una & 0.282 & 0.358 & 0.385 & 0.366 & 0.396 \\
HP & 0.215 & 0.248 & 0.243 & 0.259 & 0.274 \\
\hline
\end{tabular}

This implied that farmers in the State are still growing several crops instead of specialization in a few crops. Small size of operational holdings and fear from risk might be, among others, the main restraints to specialization of agriculture in the State. However, analysis of Herfindahl indices over a period from 1972-73 to 2011-12 revealed that Bilaspur, Chamba, Hamirpur, Kangra, Kullu, Mandi,
Solan and Una were the districts depicting a trend towards specialized agriculture at varying rates. The values of Herfindahl indices were, however, less than 0.5 for all the districts. On the contrary, Kinnaur, Lahaul \& Spiti, Shimla and Sirmour witnessed tendency towards diversified agriculture at varying extents. The pace of specialization was observed to be the highest in Hamirpur and the lowest in Kullu during the study period. Likewise, the highest rate of diversification was recorded in Kinnaur and the lowest in Shimla over the study period. Low holding size and highly risky hill agriculture could be the factors hindering crop specialization in the State.

Table 3: Herfindahl Index (HI) of different crop groups in Himachal Pradesh from 1972-73 to 2011-12

\begin{tabular}{ccccccc}
\hline & \multicolumn{6}{c}{ Crop groups and Herfindal Index (HI) } \\
\cline { 2 - 7 } Year & \multicolumn{7}{c}{ Cereals Pulses Fruits Vegetables } & $\begin{array}{c}\text { Non- } \\
\text { food } \\
\text { crops }\end{array}$ & $\begin{array}{c}\text { Total } \\
\text { Crops }\end{array}$ \\
\hline $1972-73$ & 0.305 & 0.320 & 0.554 & 0.591 & 0.174 & 0.215 \\
$1981-82$ & 0.342 & 0.275 & 0.549 & 0.504 & 0.198 & 0.248 \\
$1991-92$ & 0.368 & 0.331 & 0.587 & 0.483 & 0.212 & 0.243 \\
$2001-02$ & 0.375 & 0.375 & 0.558 & 0.262 & 0.226 & 0.259 \\
$2011-12$ & 0.384 & 0.415 & 0.683 & 0.205 & 0.227 & 0.274 \\
\hline
\end{tabular}

These indices were also worked out to examine diversification within different crop groups' viz., cereals, pulses, fruits, vegetables, non-food group and all crops together for the State at different periods of time and the results are presented in Table 3. Cereal group includes rice, wheat, barley, maize, common \& minor millets and other cereals. Pulses group includes gram, green gram, red gram, black gram, horse gram, maser, other kharif pulses, other rabi pulses. Fruit group includes apple, peaches, pears, plum, litchi, kinnow and orange, other citrus fruits, mangoes, guava, and other fresh fruits, walnut, almonds and other dry fruits. Vegetable group includes potato, brinjal, pea, sweet potato, tomato, lady finger, cauliflower and cabbage, turnip, radish, carrot, other winter vegetables and other summer vegetables. It is evident from table that situation with regard to cereals has remained almost same as shown by the values of Herfindahl index for this crop group which ranges from 0.305 to 0.384. Similar trend was observed in case of pulses and non-food crops, though the value of Herfindahl index differs between these crop groups. The table 
reflects some definite trend of diversification in the vegetable group where the Herfindahl index value has shown a decreasing trend from 0.591 in 1972-73 to 0.205 in 2011-12 indicating thereby the clear trend of diversification.

Table 4: Temporal changes in the area under nonfoodgrains crops across districts in Himachal Pradesh from 1972-73 to 2011-12 (Percent)

\begin{tabular}{cccccc}
\hline Districts & $\mathbf{1 9 7 2 - 7 3}$ & $\mathbf{1 9 8 2 - 8 3}$ & $\mathbf{1 9 9 2 - 9 3}$ & $\mathbf{2 0 0 2 - 0 3}$ & $\mathbf{2 0 1 1 - 1 2}$ \\
\hline Bilaspur & 3.01 & 3.30 & 3.24 & 2.83 & 3.38 \\
Chamba & 6.36 & 7.49 & 7.49 & 9.13 & 8.46 \\
Hamirpur & 1.38 & 1.28 & 1.28 & 1.02 & 1.22 \\
Kangra & 11.21 & 9.34 & 9.34 & 9.83 & 8.45 \\
Kinnaur & 8.09 & 14.45 & 14.45 & 33.87 & 60.80 \\
Kullu & 6.83 & 11.90 & 11.90 & 22.68 & 24.01 \\
L\&S & 24.70 & 46.97 & 46.97 & 71.96 & 82.17 \\
Mandi & 5.89 & 6.80 & 6.80 & 9.42 & 9.00 \\
Shimla & 17.16 & 20.76 & 20.76 & 48.83 & 64.66 \\
Sirmaur & 9.99 & 10.75 & 10.75 & 17.48 & 23.63 \\
Solan & 9.73 & 8.25 & 8.25 & 13.96 & 12.87 \\
Una & 7.79 & 7.83 & 7.83 & 8.18 & 9.11 \\
HP & 8.81 & 9.38 & 9.38 & 14.69 & 16.62 \\
\hline
\end{tabular}

To capture diversification in terms of increase in acreage under high value crops, changing level of area under non-food grains, was considered for the purpose. From Table 4, it can be realized that area under non-foodgrains (fruits and vegetable crops) increased continuously in the State from 8.81 per cent of total cropped area in triennium ending 197273 to 16.62 per cent in triennium ending 2011-12 i.e. it almost doubled. However, the extent of process of crop diversification varies across districts/regions due to wide heterogeneity in the agro-climatic and socio-economic conditions. It is evident that diversification towards high value cash crops in most of the districts did take place during the study period but its intensity was quite pronounced in Lahaul \& Spiti, Shimla, Kinnaur and Kullu where the increase in area under the non-foodgrains was varied from 17.18 per cent in Kullu to 57.47 per cent in Lahaul-Spiti over 1972-73.

The ongoing process of crop diversification in the state becomes evident from rising proportion of gross cropped area under fruit and vegetable crops. Table 5 portrays changes in cropping pattern in Himachal Pradesh during 1972-73 to 2011-12. Changes in cropping pattern in terms of acreage allocation among different crops are the integral part of agricultural development of any region. The area share of foodgrains has shown a declining trend between 1972-73 (91.17\%) and 2011-12 (83.38\%). It can be concluded that cropping pattern has shifted in favour of horticultural crops (apple, other fruits and other vegetables) and major cereals (maize and wheat) in the State during the study period.

The cropping pattern of sampled farms was analyzed and presented in Table-6. High value crops (fruits and vegetables) occupy the highest share in the gross cropped area at an overall basis. At an overall level in highly diversified blocks cropping intensity worked out to be 169.41 wheras, it was 145.83 in less diversified blocks and for the State as a whole cropping intensity worked out to be 157.82 per cent, which indicates the scope for improvement in farm efficiency. The cultivation

Table 5: Temporal changes in cropping pattern in Himachal Pradesh from 1972-73 to 2011-12 (Percent to total cropped area)

\begin{tabular}{cccccccccc}
\hline Crops/years & $\mathbf{1 9 7 2 - 7 3}$ & $\mathbf{1 9 7 7 - 7 8}$ & $\mathbf{1 9 8 2 - 8 3}$ & $\mathbf{1 9 8 7 - 8 8}$ & $\mathbf{1 9 9 2 - 9 3}$ & $\mathbf{1 9 9 7 - 9 8}$ & $\mathbf{2 0 0 2 - 0 3}$ & $\mathbf{2 0 0 7 - 0 8}$ & $\mathbf{2 0 1 1 - 1 2}$ \\
\hline Rice & 10.50 & 10.90 & 9.45 & 9.25 & 8.42 & 8.73 & 8.81 & 8.16 & 8.05 \\
Maize & 28.16 & 29.11 & 30.10 & 30.78 & 31.91 & 31.62 & 30.98 & 31.15 & 31.54 \\
Wheat & 34.30 & 34.30 & 39.20 & 38.50 & 38.90 & 38.26 & 38.03 & 38.05 & 38.19 \\
Barley & 4.55 & 4.04 & 3.94 & 3.23 & 2.79 & 2.81 & 2.50 & 2.44 & 2.21 \\
Other cereals & 5.90 & 4.13 & 3.40 & 2.85 & 2.08 & 1.19 & 2.17 & 0.77 & 0.76 \\
Pulses & 7.76 & 8.66 & 4.48 & 4.52 & 4.22 & 3.64 & 3.19 & 3.52 & 2.37 \\
Total food grains & 91.17 & 91.14 & 90.57 & 89.13 & 88.32 & 86.74 & 85.67 & 84.28 & 83.38 \\
Fruits & 1.79 & 2.17 & 3.00 & 3.69 & 4.78 & 5.63 & 6.51 & 7.01 & 8.54 \\
Vegetables & 2.10 & 2.17 & 2.22 & 2.85 & 2.61 & 3.42 & 3.63 & 3.71 & 4.09 \\
Oilseeds & 2.58 & 2.43 & 2.33 & 2.38 & 2.35 & 2.04 & 1.47 & 1.63 & 1.70 \\
Others & 2.36 & 2.09 & 1.88 & 1.95 & 1.94 & 2.17 & 2.72 & 3.37 & 2.29 \\
\hline
\end{tabular}


Table 6: Cropping pattern of the sampled farmers in the study area (Per cent to GCA)

\begin{tabular}{|c|c|c|c|c|c|c|c|c|c|c|c|}
\hline \multirow{2}{*}{ Crops } & \multicolumn{2}{|c|}{ Zone-I (Bilaspur) } & \multicolumn{2}{|c|}{ Zone-II (Solan) } & \multicolumn{2}{|c|}{ Zone-III (Kullu) } & \multicolumn{2}{|c|}{$\begin{array}{c}\text { Zone-IV } \\
\text { (Kinnaur) }\end{array}$} & \multirow{2}{*}{ Overall } & \multicolumn{2}{|c|}{ Overall } \\
\hline & Sadar & Jandutha & Solan & Kunihar & Kullu & Anni & Kalpa & Pooh & & $\begin{array}{l}\text { Highly } \\
\text { diversified }\end{array}$ & $\begin{array}{c}\text { Less } \\
\text { diversified }\end{array}$ \\
\hline $\begin{array}{l}\text { Cereals and } \\
\text { Pulses }\end{array}$ & 81.79 & 92.77 & 10.46 & 80.05 & 13.90 & 6.52 & 16.30 & 17.58 & 38.60 & 30.61 & 49.23 \\
\hline Vegetables & 18.21 & 7.23 & 87.00 & 19.95 & 74.55 & 15.51 & 16.30 & 22.74 & 34.84 & 49.02 & 16.36 \\
\hline Fruits & 0.00 & 0.00 & 2.54 & 0.00 & 11.55 & 77.96 & 67.41 & 59.68 & 26.56 & 20.38 & 34.41 \\
\hline $\begin{array}{l}\text { Total high } \\
\text { value crops }\end{array}$ & 18.21 & 7.23 & 89.54 & 19.95 & 86.10 & 93.47 & 83.71 & 82.42 & 61.40 & 69.40 & 50.77 \\
\hline $\begin{array}{c}\text { Cropping } \\
\text { intensity (\%) }\end{array}$ & 197.25 & 194.85 & 197.37 & 196.18 & 177.56 & 111.83 & 121.62 & 132.31 & 157.82 & 169.41 & 145.83 \\
\hline $\begin{array}{c}\text { Gross cropped } \\
\text { area (ha) }\end{array}$ & 1.505 & 1.134 & 1.577 & 0.822 & 1.108 & 1.257 & 1.080 & 1.126 & 1.201 & 1.318 & 1.085 \\
\hline $\begin{array}{l}\text { Net sown area } \\
\text { (ha) }\end{array}$ & 0.763 & 0.582 & 0.835 & 0.419 & 0.624 & 1.124 & 0.888 & 0.851 & 0.761 & 0.778 & 0.744 \\
\hline
\end{tabular}

Figures in parentheses indicate area in hectare in each case.

Table 7: Sources of gross household income in the study area (Rs. Per farm)

\begin{tabular}{|c|c|c|c|c|c|c|c|c|c|}
\hline \multirow{2}{*}{ Particulars } & \multicolumn{2}{|c|}{ Zone-I (Bilaspur) } & \multicolumn{2}{|c|}{ Zone-II (Solan) } & \multicolumn{2}{|c|}{ Zone-III (Kullu) } & \multicolumn{2}{|c|}{ Zone-IV (Kinnaur) } & \multirow{2}{*}{ Overall } \\
\hline & Sadar & Jandutha & Solan & Kunihar & Kullu & Anni & Kalpa & Pooh & \\
\hline \multicolumn{10}{|c|}{ Farm income } \\
\hline \multirow{4}{*}{$\begin{array}{l}\text { Agriculture (cereals } \\
\text { and pulses) } \\
\text { Horticulture }\end{array}$} & 38448 & 32096 & 2956 & 21425 & 4850 & 1748 & 11429 & 18994 & 16493 \\
\hline & $(8.11)$ & (7.47) & $(0.41)$ & (5.42) & $(0.83)$ & $(0.24)$ & (1.47) & $(2.46)$ & (2.70) \\
\hline & - & - & - & - & 10333 & 474895 & 529418 & 434640 & 181160 \\
\hline & & & & & $(1.77)$ & $(65.28)$ & $(67.94)$ & $(56.29)$ & $(29.68)$ \\
\hline \multirow[t]{2}{*}{ Vegetables } & 57256 & 15373 & 444714 & 61070 & 241430 & 22994 & 47914 & 130943 & 127711 \\
\hline & (12.08) & (3.58) & $(61.72)$ & $(15.45)$ & $(41.35)$ & $(3.16)$ & (6.15) & $(16.96)$ & $(20.93)$ \\
\hline \multirow[t]{2}{*}{ Animal husbandry } & 75870 & 61344 & 58860 & 69660 & 55296 & 23490 & 45675 & 46756 & 54618 \\
\hline & $(16.01)$ & $(14.28)$ & $(8.17)$ & $(17.62)$ & $(9.47)$ & $(3.23)$ & (5.86) & $(6.06)$ & $(8.95)$ \\
\hline \multirow[t]{2}{*}{ Sub -total } & 171574 & 108813 & 506530 & 152155 & 311909 & 523127 & 634436 & 631333 & 379984 \\
\hline & $(36.20)$ & $(25.33)$ & $(70.30)$ & $(38.49)$ & $(53.42)$ & $(71.90)$ & $(81.42)$ & $(81.76)$ & $(62.26)$ \\
\hline \multicolumn{10}{|c|}{ Non -farm income } \\
\hline \multirow[t]{2}{*}{ Service/ Pension } & 266610 & 296990 & 196500 & 213130 & 244350 & 188110 & 107750 & 108950 & 202798 \\
\hline & $(56.25)$ & $(69.13)$ & $(27.27)$ & $(53.91)$ & $(41.85)$ & $(25.86)$ & (13.83) & (14.11) & $(33.23)$ \\
\hline \multirow[t]{2}{*}{ Business } & 31600 & 17800 & 12400 & 21720 & 20400 & 11200 & 30000 & 28800 & 21740 \\
\hline & $(6.67)$ & $(4.14)$ & $(1.72)$ & (5.49) & (3.49) & $(1.54)$ & (3.85) & (3.73) & $(3.56)$ \\
\hline \multirow[t]{2}{*}{ Others } & 4170 & 6030 & 5100 & 8350 & 7250 & 5090 & 7050 & 3050 & 5761 \\
\hline & $(0.88)$ & $(1.40)$ & $(0.71)$ & $(2.11)$ & $(1.24)$ & $(0.70)$ & $(0.90)$ & $(0.40)$ & $(0.94)$ \\
\hline \multirow[t]{2}{*}{ Sub-total } & 302380 & 320820 & 214000 & 243200 & 272000 & 204400 & 144800 & 140800 & 230300 \\
\hline & $(63.80)$ & $(74.67$ & (29.70) & $(61.51)$ & $(46.58)$ & (28.10) & (18.58) & (18.24) & (37.74) \\
\hline \multirow{2}{*}{$\begin{array}{c}\text { Total household } \\
\text { income (₹/annum) }\end{array}$} & 473954 & 429633 & 720530 & 395355 & 583909 & 727527 & 779236 & 772133 & 610285 \\
\hline & $(100)$ & (100) & (100) & (100) & (100) & (100) & (100) & (100) & $(100)$ \\
\hline
\end{tabular}

Figures in parentheses indicate percentages to the total in each case.

of high value crops yield high net returns and has made a significant impact on the income of all the farmers in the State.

\section{Gross household income}

The effects of crop diversification on household income come out clearly from the data (Table 7). It shows that the farm income per household from all sources was significantly higher in Zone-III and IV, where the crop diversification was more extensive followed by Zone-II and I. In terms of the income contribution of agriculture including vegetables and horticulture, it accounted for about three fourths of the total household income in Zone-III and IV 
and around 50 per cent in Zone-II and around one fourth in Zone-I. On an average farm income was more than non farm income in all the zones.

\section{Determinants of diversification at macro level}

In order to identify the major determinants of diversification in the State, a step wise linear regression analysis with Herfindahl index as the dependent variable was carried out. Independent factors considered for this analysis were discussed in methodology. Agricultural crops were categorized into some major groups like cereals, pulses, food crops, Non-food crops and all crops. Crops included in cereal and pulse crop groups have been discussed earlier. Food crops group includes sugarcane, apple, potatoes, fruits and vegetables, chillies, ginger and other food crops. Non-food crops include cotton, ground nut, sesamum, rape-mustard, linseed, tea, fodder crops and other non-food crops. All crops include all the cereals, pulses, food crops and NonFood crops (Table 8).

Situation for agriculture in the state, in general, shows the importance of average size of land holding, per capita income, regulated market infrastructure and irrigated area in promoting crop diversification. In case of all crops irrigated area is negatively related with diversification index which means that if irrigated area increases, value of diversification index will decrease which means crop diversification will increase. Similar is the case of average size of land holding, if average size of land holding increases, value of index will decrease, which means crop diversification will increase. Mechanisation, urban population and high yielding varieties are three important factors which have not turned out to be significant in any of the crop group even though their importance cannot be minimized.

\section{Determinants of agricultural diversification at micro level}

The results of the analysis (Table 9) at the State level revealed that the size of holdings, family labour engaged in agriculture, ratio of gross irrigated area to gross cropped area, per hectare capital investment, age of the head of the family (experience in farming) and education of the head of the family had positive and statistically significant effect on the diversification. The effect of non-farm income was however negative and statistically significant, suggesting that higher non-farm income will cause intensification in the cropping pattern. The availability of irrigation leads the farmers definitely to shift their cropping pattern towards

Table 8: Factors affecting crop diversification in Himachal Pradesh at macro level from 1972-73 to 2011-12

\begin{tabular}{|c|c|c|c|c|c|c|}
\hline \multirow{4}{*}{ Factors } & \multicolumn{6}{|c|}{ Crop Groups and Regression coefficients } \\
\hline & & Cereals & Pulses & Food Crops & Non Food Crops & All Crops \\
\hline & $\mathbf{R}^{2}$ & .948 & .718 & .927 & .841 & .687 \\
\hline & Constant & .402 & .042 & .628 & .144 & .470 \\
\hline Rainfall $\left(X_{1}\right)$ & - & - & $.09^{* *}(0.00)$ & $.023^{*}(0.00)$ & - & - \\
\hline $\begin{array}{l}\text { High yielding Varieties } \\
\qquad\left(\mathrm{X}_{2}\right)\end{array}$ & - & - & - & - & - & - \\
\hline $\begin{array}{c}\text { Fertilizer Consumption } \\
\qquad\left(\mathrm{X}_{3}\right)\end{array}$ & - & - & - & $-3.00^{* *}(1.00)$ & $2.00^{* *}(0.00)$ & - \\
\hline Irrigated area $\left(\mathrm{X}_{4}\right)$ & - & - & - & - & - & $-6.00^{* *}(2.00)$ \\
\hline Road length $\left(\mathrm{X}_{5}\right)$ & - & $2.00^{* *}(1.00)$ & - & - & - & - \\
\hline Mechanisation $\left(X_{6}\right)$ & - & - & - & - & - & - \\
\hline Urban Population $\left(X_{7}\right)$ & - & - & - & - & - & - \\
\hline Per Capita Income $\left(\mathrm{X}_{8}\right)$ & - & $-.0007^{* *}(0.00)$ & $.013^{* *}(0.00)$ & $.0052^{* *}(0.00)$ & - & - \\
\hline $\begin{array}{c}\text { Average Size of Land } \\
\text { Holding }\left(X_{q}\right)\end{array}$ & - & $-65.0^{* *}(18.0)$ & - & - & - & $-92.00^{* *}(15.00)$ \\
\hline Regulated Markets $\left(\mathrm{X}_{10}\right)$ & - & - & $-60.00^{* *}(13.00)$ & $-18.00^{* *}(7.00)$ & - & - \\
\hline
\end{tabular}

** denotes the significance at $1 \%$ probability level, * at $5 \%$ probability level.

$b$ values and standard error are multiplied by 1000, because of small size of the values. 
Table 9: Factors affecting agricultural diversification at micro level

\begin{tabular}{cccccc}
\hline Particulars & $\begin{array}{c}\text { Zone-I } \\
\text { (Bilaspur) }\end{array}$ & Zone-II (Solan) & $\begin{array}{c}\text { Zone-III } \\
\text { (Kullu) }\end{array}$ & $\begin{array}{c}\text { Zone-IV } \\
\text { (Kinnaur) }\end{array}$ & Overall \\
\hline $\begin{array}{c}\text { Constant } \\
\text { Farm size }\end{array}$ & .287 & .376 & .722 & .692 & .092 \\
$\begin{array}{c}\text { Family members engaged in } \\
\text { agriculture }\end{array}$ & $.008^{*}(.002)$ & $.017^{*}(.002)$ & & $.009^{* * *}(.005)$ & $.013^{*}(.002)$ \\
$\begin{array}{c}\text { Ratio of gross irrigated area to } \\
\text { gross cropped area } \\
\text { Non-farm income }\end{array}$ & $.003^{*}(.001)$ & $.001^{*}(.000)$ & $.002^{*}(.001)$ & $.008^{* *}(.002)$ & $.002^{*}(.000)$ \\
$\begin{array}{c}\text { Age of the head of the family } \\
\text { Education of the head of the } \\
\text { family }\end{array}$ & & $-.00000112^{* *}(.000)$ & & \\
$\begin{array}{c}\text { Per bigha capital investment } \\
\mathrm{R}^{2}\end{array}$ & $.0000269^{* *}(.000)$ & & & & $.003^{* * *}(.002)$ \\
& & & & & $.020^{* * *}(.012)$ \\
\end{tabular}

Note: ${ }^{*}$ - Denotes the significance at $1 \%$ probability level, ${ }^{* *}$ at $5 \%$ probability level, ${ }^{* * *}$ at $10 \%$ probability level.

high value crops. In the study area the farmers have shifted their maximum irrigated area towards high value vegetable crops.

\section{CONCLUSION}

Agriculture in the State remained highly diversified over the years in 1972-73 and during 2011-12 with marginal tendency towards specialization. However, district wise analysis (HI) of the State over a period from 1972-73 to 2011-12 revealed that Kinnaur, Lahaul \& Spiti, Shimla and Sirmour were the districts depicting a trend towards diversified agriculture at varying rates. Within crop group's vegetables group indicating the clear trend of diversification. An analysis of area under non-foodgrains at the district level showed that it increased at varying rates in most of the districts (ten) while a marginal decline was observed in Hamirpur and Kangra. Farmers extracted their land resources from producing rice, other cereals' including barley and pulses and allocated it towards producing the major cereals (maize and wheat), high value crops (apple, fruits other than apple, and vegetables). These high value crops yields higher income to the farmers of the State. Average size of land holding and irrigated area were two most important determinants of agriculture diversification in Himachal Pradesh which were positively related with the agricultural diversification. It was recognized that agricultural diversification helps achieve food security and improve income of the farmers. Thus agricultural diversification is an important mechanism for economic growth.

\section{REFERENCES}

Braun Von. 1995. Agricultural commercialization: impacts on income and nutrition and implications for policy. Food Policy, 20: 140-147.

Chand Ramesh. 1996. Ecological and economic impact of horticultural development in the Himalayas: evidence from Himachal Pradesh. Economic and Political Weekly, 31: 2111-2119.

Jodha, N.S. 1992. Agricultural growth \& sustainability: perspectives and experiences from the himalayas. MFS series no.25, ICIMOD, Kathmandu, Nepal.

Joshi, P.K., Gulati Ashok and Tiwari, L. 2004. Agricultural diversification in South Asia: patterns, determinants and policy implications. Economic and Political Weekly, 39: 2457-2467.

Reynolds, L.G. 1975. Agriculture in development theory. New Haven, CT: Yale University Press Publication.

Sharma, H.R. 2005. Agricultural development and crop diversification in Himachal Pradesh: understanding the patterns, process determinants and lessons. Indian Journal of Agricultural Economics, 60: 71-93.

Todaro, M.P. 1989. Economic Development for the third world, New York: Longman Publication.

Vyas, V.S. 1996. Diversification in agriculture: concept, rationale and approach. Indian Journal of Agricultural Economics, 51: 271-278. 
